\title{
Comparison of Antioxidant and Anticancer Properties of Soft Coral-Derived Sinularin and Dihydrosinularin
}

\author{
Sheng-Chieh Wang ${ }^{1}$, Ruei-Nian Li ${ }^{1} \mathbb{D}$, Li-Ching Lin ${ }^{2,3,4}$, Jen-Yang Tang ${ }^{5,6}{ }^{\mathbb{D}}$, Jui-Hsin Su ${ }^{7,8}$, \\ Jyh-Horng Sheu 9,10,11,12,* and Hsueh-Wei Chang 1,13,14,15,16,*(D)
}

1 Department of Biomedical Science and Environmental Biology, Ph.D. Program in Life Sciences, College of Life Sciences, Kaohsiung Medical University, Kaohsiung 80708, Taiwan; u107851101@gap.kmu.edu.tw (S.-C.W.); runili@kmu.edu.tw (R.-N.L.)

2 Chi-Mei Foundation Medical Center, Department of Radiation Oncology, Tainan 71004, Taiwan; 8508a6@mail.chimei.org.tw

3 School of Medicine, College of Medicine, Taipei Medical University, Taipei 11031, Taiwan

4 Chung Hwa University of Medical Technology, Tainan 71703, Taiwan

5 School of Post-Baccalaureate Medicine, Kaohsiung Medical University, Kaohsiung 80708, Taiwan; reyata@kmu.edu.tw

6 Department of Radiation Oncology, Kaohsiung Medical University Hospital, Kaoshiung Medical University, Kaohsiung 80708, Taiwan

7 National Museum of Marine Biology \& Aquarium, Pingtung 944, Taiwan; x2219@nmmba.gov.tw

8 Institute of Marine Biotechnology, National Dong Hwa University, Pingtung 90078, Taiwan

9 Department of Marine Biotechnology and Resources, National Sun Yat-sen University,

check for updates

Citation: Wang, S.-C.; Li, R.-N.; Lin, L.-C.; Tang, J.-Y.; Su, J.-H.; Sheu, J.-H.; Chang, H.-W. Comparison of Antioxidant and Anticancer Properties of Soft Coral-Derived Sinularin and Dihydrosinularin. Molecules 2021, 26, 3853. https:// doi.org/10.3390/molecules26133853

Academic Editors: Elena Grasselli, Chiara Lambruschini, Lisa Moni and Ilaria Demori

Received: 31 May 2021

Accepted: 22 June 2021

Published: 24 June 2021

Publisher's Note: MDPI stays neutral with regard to jurisdictional claims in published maps and institutional affiliations.

Copyright: (c) 2021 by the authors. Licensee MDPI, Basel, Switzerland. This article is an open access article distributed under the terms and conditions of the Creative Commons Attribution (CC BY) license (https:/ / creativecommons.org/licenses/by/ $4.0 /)$.
Kaohsiung 80424, Taiwan

10 Doctoral Degree Program in Marine Biotechnology, National Sun Yat-sen University, Kaohsiung 80424, Taiwan

11 Department of Medical Research, China Medical University Hospital, China Medical University, Taichung 40402, Taiwan

12 Frontier Center for Ocean Science and Technology, National Sun Yat-sen University, Kaohsiung 80424, Taiwan

13 Center for Cancer Research, Kaohsiung Medical University, Kaohsiung 80708, Taiwan

14 Cancer Center, Kaohsiung Medical University Hospital, Kaohsiung Medical University, Kaohsiung 80708, Taiwan

15 Institute of Medical Science and Technology, National Sun Yat-sen University, Kaohsiung 80424, Taiwan

16 Department of Medical Research, Kaohsiung Medical University Hospital, Kaohsiung Medical University, Kaohsiung 80708, Taiwan

* Correspondence: sheu@mail.nsysu.edu.tw (J.-H.S.); changhw@kmu.edu.tw (H.-W.C.); Tel.: +886-7-525-2000 (ext. 5030) (J.-H.S.); +886-7-312-1101 (ext. 2691) (H.-W.C.)

Abstract: Marine natural products are abundant resources for antioxidants, but the antioxidant property of the soft corals-derived sinularin and dihydrosinularin were unknown. This study aimed to assess antioxidant potential and antiproliferation effects of above compounds on cancer cells, and to investigate the possible relationships between them. Results show that sinularin and dihydrosinularin promptly reacted with 2,2-diphenyl-1-picrylhydrazyl (DPPH), 2,2-azinobis (3-ethyl-benzothiazoline-6-sulfonic acid) (ABTS), and hydroxyl $(\bullet \mathrm{OH})$, demonstrating a general radical scavenger activity. Sinularin and dihydrosinularin also show an induction for $\mathrm{Fe}^{+3}$-reduction and $\mathrm{Fe}^{+2}$-chelating capacity which both strengthen their antioxidant activities. Importantly, sinularin shows higher antioxidant properties than dihydrosinularin. Moreover, $24 \mathrm{~h}$ ATP assays show that sinularin leads to higher antiproliferation of breast, lung, and liver cancer cells than dihydrosinularin. Therefore, the differential antioxidant properties of sinularin and dihydrosinularin may contribute to their differential anti-proliferation of different cancer cells.

Keywords: antioxidant; cytotoxicity; soft coral; marine natural products; sinularin; dihydrosinularin

\section{Introduction}

Oxidative stress affects cellular function. Changes in the oxidative status may generate peroxidation impacts on lipids, proteins, and RNA and regulate cell response, signaling, 
and metabolism [1,2]. Peroxidation of lipids, proteins, DNA, and RNA may damage their biological functions and provide mitochondrial dysfunction and apoptosis [3]. Peroxidations were reported to be associated with several diseases such as neurodegenerative [4], atherosclerosis [5], and kidney disorders [6]. Therefore, antioxidation would assist in avoiding such cellular and tissue damages $[7,8]$.

Marine natural compounds are rich exogenous resources of antioxidants [9-12]. Exogenous antioxidants commonly show a bi-phase oxidative stress-modulating ability towards cancer cells [13]. Compounds with antioxidant ability show different mediations of cellular oxidative stress. Exogenous antioxidants provide oxidative stress-suppressing ability at physiological concentrations, however, show oxidative stress-promoting power at cytotoxic concentrations.

Soft corals contain many bioactive natural compounds [14] that show anticancer effects [15-21]. Sinularin was isolated from the soft corals Sinularia flexibilis [22] and S. manaarensis [23]. Similarly, dihydrosinularin was firstly isolated from the soft coral S. flexibilis [24]. The IUPAC names for sinularin and dihydrosinularin are (9E)-13-hydroxy4,9,13-trimethyl-17-methylidene-5,15-dioxatricyclo[1 2.3.1.0 $\left.0^{4,6}\right]$ octadec-9-en-16-one and (9E)-13-hydroxy-4,9,13,17-tetramethyl-5,15-dioxatricyclo[1 2.3.1.0 $\left.0^{4,6}\right]$ octadec-9-en-16-one, respectively [25]. The main chemical difference between them is that sinularin possesses a conjugated double bond which lacks in dihydrosinularin.

Although sinularin and dihydrosinularin are similar marine natural compounds, they show different bioactivities if investigated as yet. The antiproliferation ability of sinularin was reported in several types of cancer cells $[16,20,22,26-29]$. However, the antiproliferation reports of dihydrosinularin are rare. Cytotoxicity of dihydrosinularin was reported with respect to lymphocytic leukemia [22], lung and colon cancer cells [30]. The antioxidant properties of these related compounds were rarely investigated. Most of those studies focused on bioactive compound identification and cancer cell cytotoxicity. They rarely reported the detailed anticancer mechanisms, especially the role of antioxidant properties providing anticancer effect.

The present study aims at the antioxidant properties through radical-scavenging activities and examines the antiproliferation effect to breast, lung, and liver cancer cells applying an ATP assay for the similar compounds sinularin and dihydrosinularin.

\section{Results}

\subsection{Radical Scavenging Activity of 2,2-Diphenyl-1-picrylhydrazyl (DPPH)}

$\mathrm{DPPH}[31]$ is a common method for detecting in vitro antioxidant properties. Figure 1A shows the structures of sinularin and dihydrosinularin. In Figure 1B, the DPPH scavenging activity of sinularin increases below a threshold of $250 \mu \mathrm{M}$ and reaches a plateau of $40 \%$ scavenging activity at $400 \mu \mathrm{M}$. DPPH scavenging activity of dihydrosinularin increases below $200 \mu \mathrm{M}$ and reaches a plateau of $10 \%$ activity at $400 \mu \mathrm{M}$. Therefore, sinularin shows higher DPPH scavenging activity than dihydrosinularin.

\subsection{Radical Scavenging Activity for 2,2-Azinobis (3-Ethyl-benzothiazoline-6-sulfonic Acid) (ABTS)}

ABTS $^{\bullet+}$ [32] is another in vitro antioxidant detection method. In Figure 2, the ABTS scavenging activity of sinularin dramatically increases to $50 \%$ at $15 \mu \mathrm{M}$ and reaches a plateau of $60 \%$ activity above $250 \mu \mathrm{M}$. ABTS scavenging activities of dihydrosinularin increase in a dose-response manner within $400 \mu \mathrm{M}$, but it gets $30 \%$ at $400 \mu \mathrm{M}$. Therefore, sinularin shows higher ABTS scavenging activity than dihydrosinularin.

\subsection{Hydroxyl $(\bullet \mathrm{OH})$ Radical Scavenging Activity}

- $\mathrm{OH}$ initiates an early stage of lipid hydroperoxidation for producing the lipid radical to trigger lipid peroxidation [33]. Accordingly, measurement of ${ }^{\bullet} \mathrm{OH}$ radical scavenging activity was also used to assess in vitro antioxidant properties [34]. In Figure 3, the ${ }^{\bullet} \mathrm{OH}$ scavenging activity of sinularin dramatically increases to $35 \%$ at $15 \mu \mathrm{M}$ and reaches plateaus 
of $60 \%$ and $70 \%$ activity at 250 and $400 \mu \mathrm{M}$, respectively. ${ }^{\circ} \mathrm{OH}$ scavenging activities of dihydrosinularin increase in a dose-response manner within the $400 \mu \mathrm{M}$ range, but it reaches only $40 \%$ at $400 \mu \mathrm{M}$. Therefore, sinularin shows higher ${ }^{\circ} \mathrm{OH}$ scavenging activity than dihydrosinularin.

A

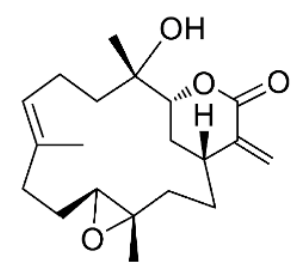

Sinularin<smiles>CC/C(C)=C\CC[C@@](C)(O)[C@H]1C[C@@]2(CC[C@@]3(C)O[C@H]3C2)[C@@H](C)C(=O)O1</smiles>

Dihydrosinularin
B

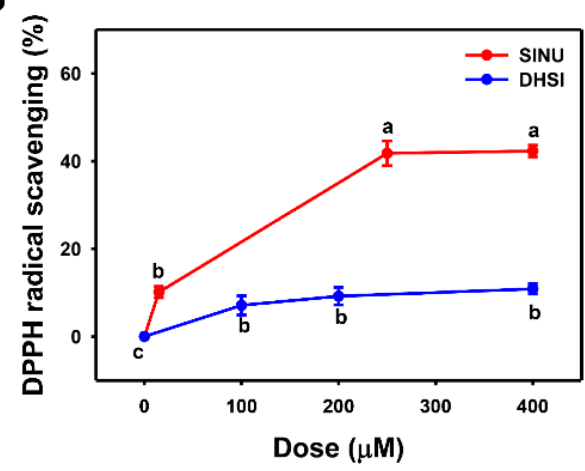

Figure 1. Structures and DPPH scavenging activities of sinularin and dihydrosinularin. (A) Structures. (B) DPPH scavenging activities. Data, mean $\pm \mathrm{SD}(n=3)$. DPPH scavenging activities for different concentrations of sinularin (SINU) and dihydrosinularin (DHSI) are compared to blank. According to multiple comparisons, data of the same characters showing non-overlap indicate significant differences $(p<0.05-0.001)$.

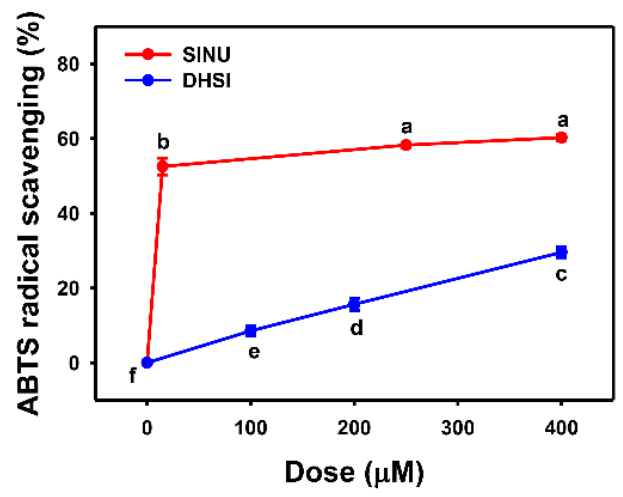

Figure 2. ABTS scavenging activities of sinularin and dihydrosinularin. Data, mean $\pm \mathrm{SD}(n=3)$. DPPH scavenging activities for different concentrations of sinularin (SINU) and dihydrosinularin (DHSI) are compared to blank. According to multiple comparisons, data of the same characters showing non-overlap indicate significant differences $(p<0.05-0.001)$.

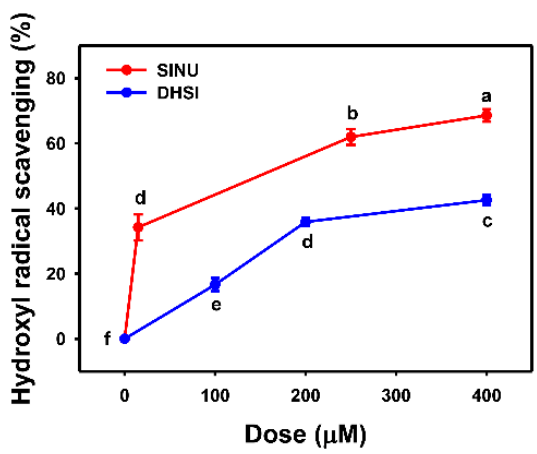

Figure 3. Hydroxyl scavenging activities of sinularin and dihydrosinularin. Data, mean $\pm \mathrm{SD}(n=3)$. DPPH scavenging activities for different concentrations of sinularin (SINU) and dihydrosinularin (DHSI) are compared to blank. According to multiple comparisons, data of the same characters showing non-overlap indicate significant differences $(p<0.05-0.001)$. 


\subsection{Ferric Ion $\left(\mathrm{Fe}^{+3}\right)$-Reducing Power}

$\mathrm{Fe}^{+3}$-reducing power is an iron-based in vitro antioxidant measurement [35]. In Figure 4, sinularin and dihydrosinularin increase $\mathrm{Fe}^{+3}$-reducing power in a dose-response manner. Sinularin shows higher $\mathrm{Fe}^{+3}$-reducing powers than dihydrosinularin.

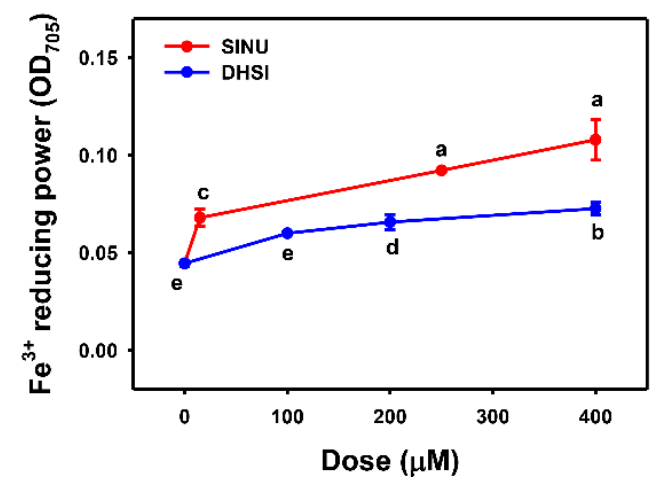

Figure 4. Ferric ions-reducing powers of sinularin and dihydrosinularin. Data, mean $\pm \operatorname{SD}(n=3)$. Ferric ions-reducing powers for different concentrations of sinularin (SINU) and dihydrosinularin (DHSI) are compared to blank. According to multiple comparisons, data of the same characters showing non-overlap indicate significant differences $(p<0.05-0.001)$.

\subsection{Ferrous Ion $\left(\mathrm{Fe}^{+2}\right)$-Chelating Capacity}

$\mathrm{Fe}^{+2}$-chelating capacity is also the iron-based in vitro antioxidant detection [35]. In Figure 5, the $\mathrm{Fe}^{+2}$-chelating capacity of sinularin dramatically increases to $6 \%$ at $15 \mu \mathrm{M}$ and reaches a plateau for $7 \%$ activity larger than $250 \mu \mathrm{M}$. Dihydrosinularin increases $\mathrm{Fe}^{+2}$ chelating capacity in a dose-response manner within $400 \mu \mathrm{M}$, but it comes $4 \%$ at $400 \mu \mathrm{M}$. Therefore, sinularin shows a higher $\mathrm{Fe}^{+2}$-chelating capacity than dihydrosinularin.

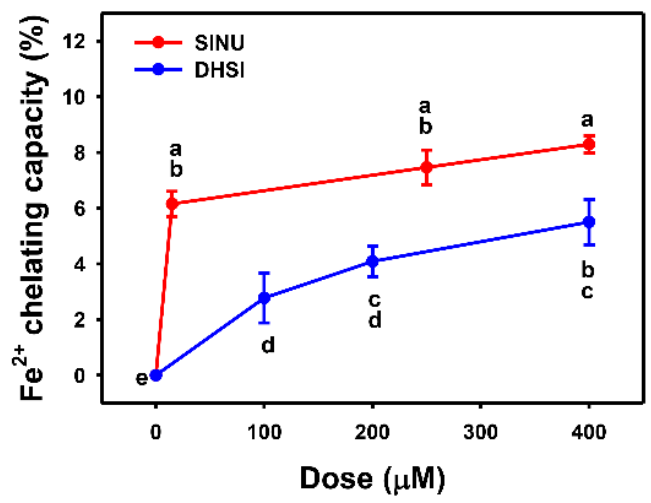

Figure 5. Ferrous ions-chelating capacities of sinularin and dihydrosinularin. Data, mean $\pm \operatorname{SD}(n=3)$. Ferrous ions-chelating capacities for different concentrations of sinularin (SINU) and dihydrosinularin (DHSI) are compared to blank. According to multiple comparisons, data of the same characters showing non-overlap indicate significant differences $(p<0.05-0.001)$.

\subsection{Cell Viabilities of Several Drug-Treated Cancer Cell Lines}

We applied an ATP assay as a mitochondrial function-based detection of cell viability [36]. In triple-negative breast MDA-MB-231, lung H1299 cells, and liver HA22T/VGH cancer cells, the $\mathrm{IC}_{50}$ values of sinularin at $24 \mathrm{~h}$ ATP assays were 32,2 , and $12 \mu \mathrm{M}$, respectively. In comparison, the $\mathrm{IC}_{50}$ values of dihydrosinularin in MDA-MB-231, H1299, and HA22T/VGH cells were 60, 70, and $120 \mu \mathrm{M}$, respectively. Therefore, sinularin shows higher antiproliferation ability than dihydrosinularin to breast, lung, and liver cancer cells. 


\section{Discussion}

The main difference between sinularin and dihydrosinularin is that sinularin, but not dihydrosinularin, has a conjugated double bond within the carbonyl group of the lactone ring. However, the antioxidant and antiproliferation abilities of sinularin and dihydrosinularin were rarely investigated. Differences between sinularin and dihydrosinularin were evaluated in the present study. The possible reasons why sinularin and dihydrosinularin exhibit differential antioxidant and antiproliferation abilities were discussed.

Different double bonds may contribute to the differential antioxidant effect. For example, polyunsaturated fatty acids (PUFA) containing many double bonds and bisallylic hydrogen atoms are easily oxidized and show antioxidant abilities [37]. Double bonds at different positions may have differential antioxidant powers. For example, isomoracin $\mathrm{C}$ contains the double bond at conjugation position, which is not the case in moracin C. Iso-moracin C shows higher antioxidative activity than moracin C [38].

Free radicals tend to directly attack the conjugated double bonds [39], indicating their potential antioxidant properties. For example, conjugated double bonds of terpenes contribute to the high antioxidant properties of free radical scavenging [40]. In contrast, blocking conjugated double bonds suppresses the antioxidant power of monoterpenes [41]. Accordingly, chemicals with conjugated double bonds exhibit a relative higher redoxrelated antioxidant power than chemicals without conjugated double bonds. However, above studies focused on the relationship of structure and antioxidant effects without aiming at possible anticancer effects.

The current study reports for the first time the antioxidant abilities of the soft-coralderived compounds sinularin and dihydrosinularin using several well-established assays. Although both sinularin and dihydrosinularin showed antioxidant properties, sinularin exhibits higher $\mathrm{DPPH}, \mathrm{ABTS}^{\bullet+}$, and ${ }^{\bullet} \mathrm{OH}$ scavenging activity as well as $\mathrm{Fe}^{+3}$-reducing power and $\mathrm{Fe}^{+2}$-chelating capacity than dihydrosinularin. We conclude that the high antioxidant ability of sinularin is probably caused from its conjugated double bond, which becomes a single bond with dihydrogen atoms in dihydrosinularin (Figure 1A).

Several marine natural products with antioxidant abilities show anticancer effects. This finding is confusing because the antioxidant is regarded as a protector from several cellular oxidative stress damages. Recently, a dual role of antioxidants has been proposed. At low concentrations of antioxidants, oxidative stress for cancer cell proliferation can be reduced. In contrast, lethal concentrations of antioxidants may induce oxidative stress that causes antiproliferation of cancer cells. Similarly, a famous natural antioxidant grape seed extract shows antioral cancer effect with oxidative stress generation at high concentrations but not at low concentrations [42]. Therefore, the exogenous antioxidant exhibits a concentrationdependent modulation of cellular oxidative stress.

As described above, lethal concentrations of antioxidants have oxidative stressgenerating potential. Since sinularin exhibits higher antioxidant effects than dihydrosinularin, it is expected that sinularin may have a higher potential to generate oxidative stress at lethal concentrations and leads to the death of cancer cells. This notion was supported by the finding that dihydrosinularin triggered oxidative stress that inhibited cell proliferation of oral [28] and renal [29] cancer cells. Consistently, the antiproliferation ability of sinularin is higher than dihydrosinularin in the example of breast and lung cancer cells (Figure 6). The higher antiproliferation ability of sinularin are explained here with its higher antioxidant ability than dihydrosinularin when high concentrations are applied to cancer cells.

In addition to their different antioxidant abilities, the more potent cytotoxicity of sinularin than dihydrosinularin is explained here with the ability of the conjugated exocyclic double bond of sinularin to form an adduct through a "Michael addition" with the thiol group of specific enzymes. This possible mechanism warrants more detailed investigations in the future. 

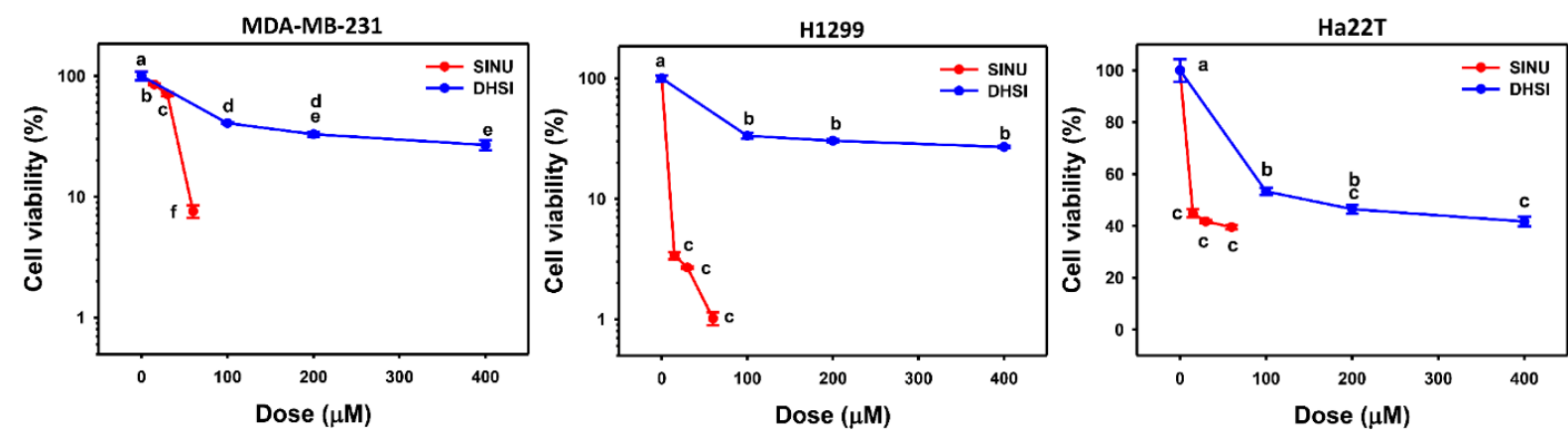

Figure 6. Cell viability of triple-negative breast and liver cancer cells following sinularin and dihydrosinularin treatments. Breast MDA-MB-231, lung H1299, and liver Ha22T cancer cells were treated with sinularin (SINU) and dihydrosinularin (DHSI) for $24 \mathrm{~h}$ incubation. Subsequently, their viabilities were determined by ATP assay (data, mean \pm SD $(n=3)$ ). According to multiple comparisons, data of the same characters showing non-overlap indicate significant differences $(p<0.05-0.001)$.

\section{Materials and Methods}

\subsection{Preparation of Two Bioactive Diterpenoids and Chemicals}

Following a previous study [23], the lyophilized bodies of the soft coral S. manaarensis were minced and extracted with ethyl acetate, and the crude extract was chromatographed to yield both cembranoids sinularin and dihydrosinularin in high purity, as confirmed by NMR spectra of the two compounds. Both of them were dissolved in ethanol for antioxidant assays and in dimethyl sulfoxide (DMSO) for cell viability assays. All chemical reagents were purchased from Sigma-Aldrich Inc (St. Louis, MO, USA).

\subsection{DPPH Radical Scavenging Activity}

The scavenging effect for DPPH was assessed as mentioned [32,43]. An amount of $125 \mu \mathrm{M} \mathrm{DPPH}$ (dissolved in ethanol) was equally mixed and reacted with either sinularin or dihydrosinularin (dissolved in ethanol) in the darkness for $30 \mathrm{~min}$. A multiplate reader (800 TS, BioTek Instruments, Inc., Winooski, VT, USA) measured the reaction at $517 \mathrm{~nm}$.

\subsection{ABTS $^{\bullet+}$ Radical Scavenging Activity}

The scavenging effect for ABTS was assessed as mentioned [32,44]. $7.4 \mathrm{mM} \mathrm{ABTS}{ }^{\bullet+} / 2.6 \mathrm{mM}$ persulfate solution was equally mixed and reacted with sinularin or dihydrosinularin (dissolved in ethanol) in the darkness for $15 \mathrm{~min}$. A multiplate reader measured the reaction at $734 \mathrm{~nm}$.

\section{4. $\bullet$ OH Radical Scavenging Activity}

The scavenging effect for ${ }^{\bullet} \mathrm{OH}$ radical was assessed as mentioned [34]. An amount of $690 \mu \mathrm{L}$ of $2.5 \mathrm{mM}$ 2-deoxyribose (in phosphate buffer (0.2 M, pH 7.4) and $100 \mu \mathrm{L}$ of $0.1 \mathrm{mM} \mathrm{FeCl}_{3}$ (dissolved in $1.04 \mathrm{mM}$ EDTA) were mixed with $100 \mu \mathrm{L}$ of sinularin or dihydrosinularin (dissolved in ethanol). Subsequently, they were allowed to react with the mixture $\left(100 \mu \mathrm{L}\right.$ of $10 \mathrm{mM}$ ascorbic acid and $10 \mu \mathrm{L}$ of $\left.0.1 \mathrm{M} \mathrm{H}_{2} \mathrm{O}_{2}\right)$ at $37^{\circ} \mathrm{C}$ for $10 \mathrm{~min}$. Finally, they were combined with a mixture $(500 \mu \mathrm{L}$ of $1 \%$ thiobarbituric acid (TBA) and $1000 \mu \mathrm{L}$ of $2.8 \%$ trichloroacetic acid (TCA)) for $10 \mathrm{~min}$. A multiplate reader measured the reaction at $532 \mathrm{~nm}$.

\section{5. $\mathrm{Fe}^{+3}$-Reducing Power}

Reducing power was assessed as mentioned [31,44]. $100 \mu \mathrm{L}$ of $0.2 \mathrm{M}$ phosphate buffer (pH 6.6) and $100 \mu \mathrm{L}$ of $1 \%$ potassium ferricyanide were reacted with $100 \mu \mathrm{L}$ of sinularin or dihydrosinularin (dissolved in ethanol) at $50{ }^{\circ} \mathrm{C}$ for $20 \mathrm{~min}$. Subsequently, they were reacted with the mixture ( $500 \mu \mathrm{L}$ of $2 \%$ TCA and $400 \mu \mathrm{L}$ of $0.1 \% \mathrm{FeCl}_{3}$ ) for $15 \mathrm{~min}$. A multiplate reader measured the reaction at $705 \mathrm{~nm}$. 


\section{6. $\mathrm{Fe}^{+2}$-Chelating Capacity}

Chelating capacity was assessed as mentioned [44]. $740 \mu \mathrm{L}$ of deionized water was mixed with $20 \mu \mathrm{L}$ of $2 \mathrm{mM} \mathrm{FeCl}_{2}$ to react with $200 \mu \mathrm{L}$ of sinularin or dihydrosinularin (dissolved in ethanol). Subsequently, they were reacted in shaking with $40 \mu \mathrm{L}$ of $5 \mathrm{mM}$ ferrozine for $10 \mathrm{~min}$. A multiplate reader measured the reaction at $562 \mathrm{~nm}$.

\subsection{Cell Viability}

Human triple-negative breast (MDA-MB-231) and lung (H1299) cancer cell lines were obtained from ATCC, and liver (HA22T/VGH) cancer cell lines were obtained from Bioresource Collection and Research Center (Hsinchu, Taiwan). These cell lines were maintained by DMEM medium (Gibco, Grand Island, NY, USA) containing $10 \%$ fetal bovine serum (FBS) and antibiotics as previously described [45]. Cell viabilities following sinularin and dihydrosinularin exposure were assessed at $24 \mathrm{~h}$ incubation using an ATP detection kit (PerkinElmer Life Sciences, Boston, MA, USA) [46]. A microplate luminometer (Berthold Technologies GmbH \& Co., Bad Wildbad, Germany) measured the light reaction.

\subsection{Statistical Analysis}

The analysis of variance (ANOVA) followed by a HSD Post-Hoc Test were applied for significance analysis. Data showing non-overlapping the same characters indicate a significant difference in multiple comparisons.

\section{Conclusions}

Antioxidants exhibit a comprehensive biological function. A similar chemical structure may demonstrate different antioxidant power. For the first time, the current study reported the antioxidant ability of marine coral-derived sinularin and dihydrosinularin by using several well-established in vitro assays. The antioxidant properties of sinularin were higher than those of dihydrosinularin. This high antioxidant power of sinularin at lethal concentrations may generate high oxidative stress. This explains our observation that sinularin has higher antiproliferation abilities than dihydrosinularin in breast, lung, and liver cancer cells.

Author Contributions: Conceptualization, J.-H.S. (Jyh-Horng Sheu) and H.-W.C.; Data curation, S.-C.W.; Formal analysis, S.-C.W. and J.-H.S. (Jui-Hsin Su); Methodology, L.-C.L., J.-Y.T., J.-H.S. (Jui-Hsin Su), R.-N.L.; Supervision, J.-H.S. (Jyh-Horng Sheu) and H.-W.C.; Writing-original draft, S.-C.W., J.-H.S. (Jyh-Horng Sheu), and H.-W.C.; Writing-review and editing, J.-H.S. (Jyh-Horng Sheu) and H.-W.C. All authors have read and agreed to the published version of the manuscript.

Funding: This work was partly supported by funds of the Ministry of Science and Technology (MOST 104-2320-B-110-001-MY2, MOST 107-2320-B-110-001-MY3, and MOST 108-2320-B-037-015-MY3), the National Sun Yat-sen University-KMU Joint Research Project (\#NSYSUKMU 109-I002 and \#NSYSUKMU 110-P016), the Kaohsiung Medical University Hospital (KMUH109-9M56), the Kaohsiung Medical University Research Center (KMU-TC108A04), and the Health and Welfare Surcharge of Tobacco Products, the Ministry of Health and Welfare, Taiwan (MOHW 110-TDU-B-212-144016).

Institutional Review Board Statement: Not applicable.

Informed Consent Statement: Not applicable.

Data Availability Statement: Not applicable.

Acknowledgments: The authors thank our colleague Hans-Uwe Dahms for editing the manuscript.

Conflicts of Interest: The authors confirm that this article content has no conflict of interest.

Sample Availability: Samples of the compounds are not available from the authors. 


\section{References}

1. Dharshini, L.C.P.; Vishnupriya, S.; Sakthivel, K.M.; Rasmi, R.R. Oxidative stress responsive transcription factors in cellular signalling transduction mechanisms. Cell. Signal. 2020, 72, 109670. [CrossRef]

2. Chmielowska-Bak, J.; Izbianska, K.; Deckert, J. Products of lipid, protein and RNA oxidation as signals and regulators of gene expression in plants. Front. Plant. Sci. 2015, 6, 405. [PubMed]

3. Panov, A.V.; Dikalov, S.I. Cardiolipin, perhydroxyl radicals, and lipid peroxidation in mitochondrial dysfunctions and aging. Oxidative Med. Cell. Longev. 2020, 2020, 1323028. [CrossRef]

4. Singh, A.; Kukreti, R.; Saso, L.; Kukreti, S. Oxidative stress: A key modulator in neurodegenerative diseases. Molecules 2019, 24, 1583. [CrossRef] [PubMed]

5. Gianazza, E.; Brioschi, M.; Martinez Fernandez, A.; Casalnuovo, F.; Altomare, A.; Aldini, G.; Banfi, C. Lipid peroxidation in atherosclerotic cardiovascular diseases. Antioxid. Redox. Signal. 2021, 34, 49-98. [CrossRef] [PubMed]

6. Sidhom, E.H.; Kim, C.; Kost-Alimova, M.; Ting, M.T.; Keller, K.; Avila-Pacheco, J.; Watts, A.J.; Vernon, K.A.; Marshall, J.L.; Reyes-Bricio, E.; et al. Targeting a Braf/Mapk pathway rescues podocyte lipid peroxidation in CoQ-deficiency kidney disease. J. Clin. Investig. 2021, 131, 141380. [CrossRef]

7. Matallana-González, M.C.; Cámara, M.; Fernández-Ruiz, V.; Morales, P. Antioxidant phytochemicals in pulses and their relation to human health: A Review. Curr. Pharm. Des. 2020, 26, 1880-1897.

8. Wall-Medrano, A.; Olivas-Aguirre, F.J. Antioxidant phytochemicals in cancer prevention and therapy-An update. In Functional Foods in Cancer Prevention and Therapy; Elsevier: Amsterdam, The Netherlands, 2020; pp. 195-220.

9. Lee, J.C.; Hou, M.F.; Huang, H.W.; Chang, F.R.; Yeh, C.C.; Tang, J.Y.; Chang, H.W. Marine algal natural products with antioxidative, anti-inflammatory, and anti-cancer properties. Cancer Cell Int. 2013, 13, 55. [CrossRef]

10. Camara, R.B.; Costa, L.S.; Fidelis, G.P.; Nobre, L.T.; Dantas-Santos, N.; Cordeiro, S.L.; Costa, M.S.; Alves, L.G.; Rocha, H.A. Heterofucans from the brown seaweed Canistrocarpus cervicornis with anticoagulant and antioxidant activities. Mar. Drugs 2011, 9 , 124-138. [CrossRef]

11. Zhong, Q.; Wei, B.; Wang, S.; Ke, S.; Chen, J.; Zhang, H.; Wang, H. The antioxidant activity of polysaccharides derived from marine organisms: An overview. Mar. Drugs 2019, 17, 674. [CrossRef]

12. Balakrishnan, D.; Kandasamy, D.; Nithyanand, P. A review on antioxidant activity of marine organisms. Int. J. Chem. Tech. Res. 2014, 6, 3431-3436.

13. Bouayed, J.; Bohn, T. Exogenous antioxidants-Double-edged swords in cellular redox state: Health beneficial effects at physiologic doses versus deleterious effects at high doses. Oxidative Med. Cell. Longev. 2010, 3, 228-237. [CrossRef]

14. Rodrigues, I.G.; Miguel, M.G.; Mnif, W. A brief review on new naturally occurring cembranoid diterpene derivatives from the soft corals of the Genera Sarcophyton, Sinularia, and Lobophytum since 2016. Molecules 2019, 24, 781. [CrossRef] [PubMed]

15. Weng, J.R.; Chiu, C.F.; Hu, J.L.; Feng, C.H.; Huang, C.Y.; Bai, L.Y.; Sheu, J.H. A sterol from soft coral induces apoptosis and autophagy in MCF-7 breast cancer cells. Mar. Drugs 2018, 16, 238. [CrossRef]

16. Huang, H.W.; Tang, J.Y.; Ou-Yang, F.; Wang, H.R.; Guan, P.Y.; Huang, C.Y.; Chen, C.Y.; Hou, M.F.; Sheu, J.H.; Chang, H.W. Sinularin selectively kills breast cancer cells showing G2/M arrest, apoptosis, and oxidative DNA damage. Molecules 2018, 23, 849. [CrossRef] [PubMed]

17. Tsai, T.C.; Lai, K.H.; Su, J.H.; Wu, Y.J.; Sheu, J.H. 7-Acetylsinumaximol B induces apoptosis and autophagy in human gastric carcinoma cells through mitochondria dysfunction and activation of the PERK/eIF2alpha/ATF4/CHOP signaling pathway. Mar. Drugs 2018, 16, 104. [CrossRef] [PubMed]

18. Lin, M.X.; Lin, S.H.; Li, Y.R.; Chao, Y.H.; Lin, C.H.; Su, J.H.; Lin, C.C. Lobocrassin B induces apoptosis of human lung cancer and inhibits tumor xenograft growth. Mar. Drugs 2017, 15, 378. [CrossRef] [PubMed]

19. Chang, Y.T.; Huang, C.Y.; Li, K.T.; Li, R.N.; Liaw, C.C.; Wu, S.H.; Liu, J.R.; Sheu, J.H.; Chang, H.W. Sinuleptolide inhibits proliferation of oral cancer Ca9-22 cells involving apoptosis, oxidative stress, and DNA damage. Arch. Oral Biol. 2016, 66, 147-154. [CrossRef]

20. Chung, T.W.; Lin, S.C.; Su, J.H.; Chen, Y.K.; Lin, C.C.; Chan, H.L. Sinularin induces DNA damage, G2/M phase arrest, and apoptosis in human hepatocellular carcinoma cells. BMC Complement. Altern. Med. 2017, 17, 62. [CrossRef]

21. Chao, C.H.; Li, W.L.; Huang, C.Y.; Ahmed, A.F.; Dai, C.F.; Wu, Y.C.; Lu, M.C.; Liaw, C.C.; Sheu, J.H. Isoprenoids from the soft coral Sarcophyton glaucum. Mar. Drugs 2017, 15, 202. [CrossRef]

22. Weinheimer, A.J.; Matson, J.A.; Hossain, M.B.; van der Helm, D. Marine anticancer agents: Sinularin and dihydrosinularin, new cembranolides from the soft coral, Sinularia flexibilis. Tetrahedron Lett. 1977, 18, 2923-2926. [CrossRef]

23. Su, J.H.; Ahmed, A.F.; Sung, P.J.; Chao, C.H.; Kuo, Y.H.; Sheu, J.H. Manaarenolides A-I, diterpenoids from the soft coral Sinularia manaarensis. J. Nat. Prod. 2006, 69, 1134-1139. [CrossRef]

24. Sanduja, R.; Sanduja, S.K.; Weinheimer, A.J.; Alam, M.; Martin, G.E. Isolation of the cembranolide diterpenes dihydrosinularin and 11-epi-sinulariolide from the marine mollusk Planaxis sulcatus. J. Nat. Prod. 1986, 49, 718-719. [CrossRef] [PubMed]

25. Kim, S.; Chen, J.; Cheng, T.; Gindulyte, A.; He, J.; He, S.; Li, Q.; Shoemaker, B.A.; Thiessen, P.A.; Yu, B.; et al. PubChem 2019 update: Improved access to chemical data. Nucleic Acids Res. 2019, 47, D1102-D1109. [CrossRef]

26. Su, T.R.; Lin, J.J.; Chiu, C.C.; Chen, J.Y.; Su, J.H.; Cheng, Z.J.; Hwang, W.I.; Huang, H.H.; Wu, Y.J. Proteomic investigation of anti-tumor activities exerted by sinularin against A2058 melanoma cells. Electrophoresis 2012, 33, 1139-1152. [CrossRef] 
27. Wu, Y.J.; Wong, B.S.; Yea, S.H.; Lu, C.I.; Weng, S.H. Sinularin induces apoptosis through mitochondria dysfunction and inactivation of the PI3K/Akt/mTOR Pathway in gastric carcinoma cells. Mar. Drugs 2016, 14, 142. [CrossRef]

28. Chang, Y.T.; Wu, C.Y.; Tang, J.Y.; Huang, C.Y.; Liaw, C.C.; Wu, S.H.; Sheu, J.H.; Chang, H.W. Sinularin induces oxidative stress-mediated G2/M arrest and apoptosis in oral cancer cells. Environ. Toxicol. 2017, 32, 2124-2132. [CrossRef]

29. Ma, Q.; Meng, X.Y.; Wu, K.R.; Cao, J.Z.; Yu, R.; Yan, Z.J. Sinularin exerts anti-tumor effects against human renal cancer cells relies on the generation of ROS. J. Cancer 2019, 10, 5114-5123. [CrossRef] [PubMed]

30. Hsieh, P.W.; Chang, F.R.; McPhail, A.T.; Lee, K.H.; Wu, Y.C. New cembranolide analogues from the formosan soft coral Sinularia flexibilis and their cytotoxicity. Nat. Prod. Res. 2003, 17, 409-418. [CrossRef] [PubMed]

31. Kunnaja, P.; Chansakaow, S.; Wittayapraparat, A.; Yusuk, P.; Sireeratawong, S. In vitro antioxidant activity of Litsea martabanica root extract and its hepatoprotective effect on chlorpyrifos-induced toxicity in rats. Molecules 2021, 26, 1906. [CrossRef]

32. Lo, S.; Leung, E.; Fedrizzi, B.; Barker, D. Synthesis, antiproliferative activity and radical scavenging ability of 5-O-acyl derivatives of quercetin. Molecules 2021, 26, 1608. [CrossRef]

33. Toyokuni, S.; Ikehara, Y.; Kikkawa, F.; Hori, M. (Eds.) Regulation of cell membrane transport by plasma. In Plasma Medical Science; Academic Press: Cambridge, MA, USA, 2019; pp. 173-247.

34. Cao, W.; Chen, W.J.; Suo, Z.R.; Yao, Y.P. Protective effects of ethanolic extracts of buckwheat groats on DNA damage caused by hydroxyl radicals. Food Res. Int. 2008, 41, 924-929. [CrossRef]

35. Erdogan-Orhan, I.; Sever-Yilmaz, B.; Altun, M.L.; Saltan, G. Radical quenching activity, ferric-reducing antioxidant power, and ferrous ion-chelating capacity of 16 Ballota species and their total phenol and flavonoid contents. J. Med. Food 2010, 13, 1537-1543. [CrossRef] [PubMed]

36. Yu, T.J.; Tang, J.Y.; Lin, L.C.; Lien, W.J.; Cheng, Y.B.; Chang, F.R.; Ou-Yang, F.; Chang, H.W. Withanolide C inhibits proliferation of breast cancer cells via oxidative stress-mediated apoptosis and DNA damage. Antioxidants 2020, 9, 873. [CrossRef] [PubMed]

37. Prisacaru, A.E. Effect of antioxidants on polyunsaturated fatty acids-Review. Acta Sci. Pol. Technol. Aliment. 2016, 15, 121-129. [CrossRef] [PubMed]

38. Li, X.; Xie, H.; Zhan, R.; Chen, D. Effect of double bond position on 2-phenyl-benzofuran antioxidants: A comparative study of moracin C and iso-moracin C. Molecules 2018, 23, 754. [CrossRef] [PubMed]

39. Oyman, Z.O.; Ming, W.; van der Linde, R. Oxidation of drying oils containing non-conjugated and conjugated double bonds catalyzed by a cobalt catalyst. Prog. Org. Coat. 2005, 54, 198-204. [CrossRef]

40. Wojtunik-Kulesza, K.A.; Ciesla, L.M.; Waksmundzka-Hajnos, M. Approach to determination a structure-Antioxidant activity relationship of selected common terpenoids evaluated by ABTS ${ }^{+}$radical cation assay. Nat. Prod. Commun. 2018, 13, 295-298. [CrossRef]

41. Wojtunik, K.A.; Ciesla, L.M.; Waksmundzka-Hajnos, M. Model studies on the antioxidant activity of common terpenoid constituents of essential oils by means of the 2,2-diphenyl-1-picrylhydrazyl method. J. Agric. Food Chem. 2014, 62, 9088-9094. [CrossRef]

42. Tang, J.Y.; Ou-Yang, F.; Hou, M.F.; Huang, H.W.; Wang, H.R.; Li, K.T.; Fayyaz, S.; Shu, C.W.; Chang, H.W. Oxidative stressmodulating drugs have preferential anticancer effects-Involving the regulation of apoptosis, DNA damage, endoplasmic reticulum stress, autophagy, metabolism, and migration. Semin. Cancer Biol. 2019, 58, 109-117. [CrossRef]

43. Wang, K.C.; Liu, Y.C.; El-Shazly, M.; Shih, S.P.; Du, Y.C.; Hsu, Y.M.; Lin, H.Y.; Chen, Y.C.; Wu, Y.C.; Yang, S.C.; et al. The antioxidant from ethanolic extract of Rosa cymosa fruits activates phosphatase and tensin homolog in vitro and in vivo: A new insight on its antileukemic effect. Int. J. Mol. Sci. 2019, 20, 1935. [CrossRef] [PubMed]

44. Yeh, C.C.; Huang, H.W.; Wu, Y.C.; Chung, C.C.; Yuan, S.S.F.; Chang, F.R.; Chang, H.W. Antioxidant potential of solvent partitioned extraction from aqueous extract of Gracilaria tenuistipitata. Curr. Org. Chem. 2015, 19, 39-44. [CrossRef]

45. Yen, C.Y.; Chiu, C.C.; Haung, R.W.; Yeh, C.C.; Huang, K.J.; Chang, K.F.; Hseu, Y.C.; Chang, F.R.; Chang, H.W.; Wu, Y.C. Antiproliferative effects of goniothalamin on Ca9-22 oral cancer cells through apoptosis, DNA damage and ROS induction. Mutat. Res. 2012, 747, 253-258. [CrossRef]

46. Chen, C.Y.; Yen, C.Y.; Wang, H.R.; Yang, H.P.; Tang, J.Y.; Huang, H.W.; Hsu, S.H.; Chang, H.W. Tenuifolide B from Cinnamomum tenuifolium stem selectively inhibits proliferation of oral cancer cells via apoptosis, ROS generation, mitochondrial depolarization, and DNA damage. Toxins 2016, 8, 319. [CrossRef] [PubMed] 